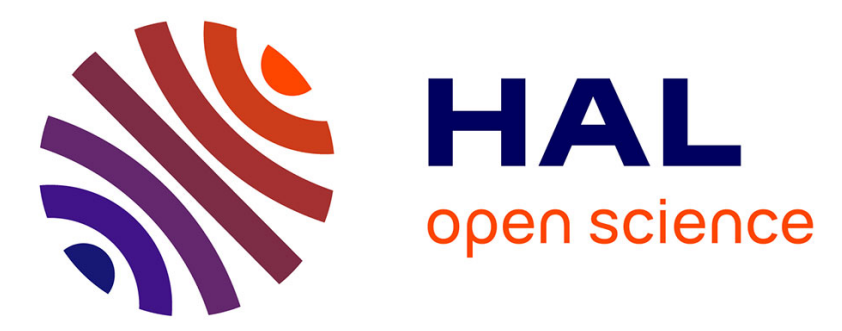

\title{
Correlation between the wear behaviour and the mechanical properties of several surface treatments
}

L. Lelait, A. Lina, R. Rezakhanlou, J. van Duysen, J. von Stebut

\section{To cite this version:}

L. Lelait, A. Lina, R. Rezakhanlou, J. van Duysen, J. von Stebut. Correlation between the wear behaviour and the mechanical properties of several surface treatments. Journal de Physique IV Proceedings, 1993, 03 (C7), pp.C7-967-C7-970. 10.1051/jp4:19937149 . jpa-00251771

\section{HAL Id: jpa-00251771 https://hal.science/jpa-00251771}

Submitted on 1 Jan 1993

HAL is a multi-disciplinary open access archive for the deposit and dissemination of scientific research documents, whether they are published or not. The documents may come from teaching and research institutions in France or abroad, or from public or private research centers.
L'archive ouverte pluridisciplinaire HAL, est destinée au dépôt et à la diffusion de documents scientifiques de niveau recherche, publiés ou non, émanant des établissements d'enseignement et de recherche français ou étrangers, des laboratoires publics ou privés. 


\title{
Correlation between the wear behaviour and the mechanical properties of several surface treatments
}

\author{
L. LELAIT, A. LINA, R. REZAKHANLOU, J.C. VAN DUYSEN and J. VON STEBUT* \\ EDF, Les Renardières, Direction des Etudes et Recherches, 77250 Moret sur Loing, France \\ ${ }^{*}$ LSGS, Ecole des Mines, Parc de Saurupt, 54042 Nancy, France
}

\begin{abstract}
Surface mechanical strength of chromium base (electrolytic and plasma sprayed) coatings is studied for friction and wear applications in nuclear environment. Indentation, scratch, and wear testing results are compared. In particular intrinsic coating brittleness is investigated as a mechanism responsible for impact wear. Electrolytic, hard chromium plate has a wear resistance well below that of the spray coated specimens studied. Acoustic emission level and brittle damage features are shown to be correlated.
\end{abstract}

\section{Introduction}

The power of a nuclear reactor is controlled by means of a set of stainless steel (AISI 304 L) tubes that have to go all the way down to the reactor core, transmitting with high prescision and continuously the strokes generated by a remote driving system. Because of their considerable length (approximately $4 \mathrm{~m}$ ) these control rods must be guided by cylinder liners, and the associated wear is a serious problem to be coped with.

In principle, wear of mechanical parts under such severe operation conditions can be reduced by hard surface coatings. For big parts conventional techniques like electrolytic, hard chromium plate and plasma spraying are possible solutions commonly available. What is needed in the present situation are well adhering, medium thick, hard coatings with good intrinsic corrosion resistance and long service life.

For reasons of nuclear safety particular care is necessary when testing mechnical strength and wear resistance of such coated parts. There is a definite need for quick, reliable laboratory mechanical testing like indentation for gross brittlenes assessment, scratch testing to yield information on surface damage under single stroke sliding contact, and multipass operation for fatigue failure reconnaissance. While these techniques are precious for pertinent surface damage diagnosis they must be ultimately accompanied by model wear experiments.

The present study is an attempt to find an efficient test procedure wich allow ultimately a predictive quality control.

\section{Experimental details}

\subsection{Specimens}

Substrates were 5 and $10 \mathrm{~mm}$ thick flats of AISI $304 \mathrm{~L}$ stainless steel. A final, special grinding procedure prior to coating would yield a surface roughness $\mathrm{Ra}=0.2 \mu \mathrm{m}$ and a hardness of $180 \mathrm{Hv} 0.2$.

Coatings of $30 \mu \mathrm{m}$ to $50 \mu \mathrm{m}$ in thickness were prepared by the following standard techniques ; conventional electrolytic chromium plate ( coating "Cr-E"), hypersonic plasma spraying of $\mathrm{Cr}_{3} \mathrm{C}_{2}$ particles in a $\mathrm{Ni80Cr} 20$ binder (coatings " $\mathrm{Cr}_{3} \mathrm{C}_{2}-\mathrm{DG}$ " and " $\mathrm{Cr}_{3} \mathrm{C}_{2}$-JK").

In the latter category two commercially available techniques were retained yielding somewhat porous and heterogeneous coatings: coating " $\mathrm{Cr}_{3} \underline{\mathrm{C}}_{2}-\underline{\mathrm{DG}}$ " was realized by detonation gun, coating " $\mathrm{Cr}_{2} \underline{\mathrm{C}_{2}-\mathrm{JK}^{\prime}}$ was obtained by means of the "Jet Kote" technique.

The final specimen characteristics thus obtained are compiled in table I. As evident from these data the composite hardness of the coating as quantified by the scrach hardness measured under $10 \mathrm{~N}$ normal load (computed assuming load to be carried by the front half of the $\mathrm{R}=0.2 \mathrm{~mm}$ Rockwell $\mathrm{C}$ diamond's spherical tip) is not just proportional to the hardness of the carbide phase. With penetration depths of approximately 2.5 mm Bückle's $1 / 10^{\prime \prime}$ criterion is well respected and the computed scratch hardness should be entirely coating specific. 


\subsection{Surface mechanical testing}

\subsubsection{High load Vickers indentation}

Qualitative brittleness assessment (crack pattern analysis) was done by means of a CSEM Revetest automatic scratch tester, mounted with a Vickers indenter and operated in the static loading mode. In case of gross, brittle cracking, on-line acoustic emission will allow for direct identification of the corresponding, critical cracking loads. Most of the time post test inspection of the remanent indent by means of the metallographic microscope accessory is the only convenient way of getting such information.

\subsubsection{Scratch testing}

Scratch testing was done with the above mentioned CSEM Revetest, according to recent recommendations of a European standardization draft. Progressive, linear loading was adopted for gross failure mechanism reconnaissance, while constant loading at distinct load levels was chosen for scratch hardness assessment as well as statistical failure analysis along the track. The major damage criteria retained in the present study were failure modes and the associated normal loads for critical cracking events generated in the track by the Rockwell $\mathrm{C}$ diamond indenter. $\mathrm{L}_{\mathrm{C} 1}$ and $\mathrm{L}_{\mathrm{C} 2}$ indicate the critical loads for brittle cracking and for major cohesive or adhesive failure along the track.

\subsubsection{Wear testing}

A CSEM high temperature pin on disc tribometer was chosen for wear testing. It was operated at $25^{\circ} \mathrm{C}$ and $320^{\circ} \mathrm{C}$ under the following general contact conditions : pin material ( $\varnothing 1 \mathrm{~mm}$, flat, cemented carbide cylinders), normal load $(P=10 \mathrm{~N})$, sliding speed $(\mathrm{v}=0.2 \mathrm{~m} / \mathrm{s})$, friction cycles $\left(\mathrm{N}=10^{5}\right)$

A special, automatic lever could be actuated once per cycle to allow for low amplitude impact simulation as occurring between the control rods and the cylinder liners of a nuclear reactor.

\subsection{Surface damage diagnosis and quantification}

First order analysis of surface damage was done by means of reflected light metallographic microscopy (RLM), completed by scanning electron microscopy (SEM), whenever necessary. No surface chemical analysis (EDX and/or EPMA) was attempted in the present study.

Wear was quantified mainly by weighing. In some cases scanning stylus profilometry (SSP) was added (sliding wear only) for wear mode analysis and wear volume checking.

\section{Results and Discussion}

\subsection{High load Vickers indentation}

The dominating damage features are tensile type, tangential cracks for all of them. The necessary critical loads are clearly lowest for the common, electrolytic chromium plate, $\mathrm{Cr}-\mathrm{E}$, for which even at low load $(20 \mathrm{~N})$ nested cracks clearly indicate that indentation has been pushed well beyond the critical level. Only for this latter coating some indication of radial cracking is observed. Its is worth underlining, that most brittleness determinations in Vickers indentation are based on the length of such radial cracks emerging from the indent corners. At the lower indention loads $(20 \mathrm{~N})$ no cracking is observed for the two spray coated specimens. The critical loads for all of them are compiled in table II.

\subsection{Scratch testing}

No adhesive failure was observed within the selected load range $(<100 \mathrm{~N})$. As in indentation, brittle, tensile type damage prevails for all three coatings as the basic damage mechanism at low loads. This is patent from the semi-circular cracks open towards the leading edge and generated behind the trailing edge of the progressing diamond indenter. Again the electroytic chromium plate is clearly the most brittle coating with cracks reaching out well beyond the lateral track rims. On the contrary, for the two spray coated specimens 
cracks are well confined to the very scratch tracks. Closer inspection reveals them to be triggered by surface defects (inclusions, growth defects, grain boundaries, porosities etc.).

Another indication of a basic difference in surface brittleness is an undeniable rise in acoustic emission (A.E.) of the $\mathrm{Cr}-\mathrm{E}$ coating with the onset of cracking (indicative of important, elastic strain energy release) whereas the two spray coated specimens yield absolutely no A.E. signal (at least 3 to 4 orders of magnitude smaller A.E.-level). The absence of any A.E. signal, in spite of clearly visible cracks, may thus be a positive indication of subcritical damage, instead of being considered as an essentially useless information neglected for any practical purpose.

Quantitative data for brittle surface damage in scratch testing under standard, progressive as well as constant load operation at $\mathrm{P}=20 \mathrm{~N}$ are compiled in table II together with corresponding data established in static Vickers indentation. In column 4 only big cracks extending over at least half of the track width have been counted. Otherwise comparison with data for electrolytic chromium plate, where this is the dominating crack size, would have been a problem. Inspection of these numerical data together with the corresponding micrographs clearly prooves the basic difference in crack behaviour, much more severe for $\mathrm{Cr}-\mathrm{E}$ than for the two spray coated specimens. Table II also shows the correlation between crack density and critical tensile type cracking loads. With cracking being exclusively triggered by statistically distributed flaws in the coatings and/or at the substrate/coating interface, the crack density criterion is undoubtedly the physically most meaningful parameter.

\subsection{Wear}

Apparently the paramount surface damage mechanism for all of the coatings studied is brittlenes. Especially for the electroytic chromium plate this parameter can be expected to play a major role in wear resistance. Quantitative data are compiled in table III for the three coatings with special attention focused on the comparison of sliding and impact/sliding wear, both at $25^{\circ} \mathrm{C}$ and $320^{\circ} \mathrm{C}$. Metallographic inspection of the wear tracks does not reveal any direct evidence of cracking damage comparable to indentation and scratch testing.

\subsubsection{Abrasive/oxidation wear of the spray coated specimens}

At room temperature, sliding and impact/sliding operation yield comparable, low levels of wear, which is practically confined to truncation of part of the surface roughness. Operation at $320^{\circ} \mathrm{C}$ will enhance wear by almost one order of magnitude. Metallographic inspection of the wear tracks shows a build up of reaction layers. The shape of the wear track (cf. Fig. 4) suggests considerable participation of wear debris as abrasivec agents under the cemented carbide rider. The presence of such wear debris in our simulative experiments should attenuate impact wear and thus account for the essentially identical results for pure sliding and impact/sliding operation.

When comparing the volume loss of specimen Cr3C2-DG as assessed by weighing and by 3D SSP there is an apparent contradiction which has still to be clarified by future experiments. In particular, we shall examine whether weight increase due to surface oxidation can account for this discrepancy.

\subsubsection{Brittle and abrasive wear of electrolytic, hard chromium plate}

There is a striking influence of impact wear in the case of hard chromium plate. Table III clearly shows that detrimental failure, due to total coating evacuation at room temperature occurs after 35000 turns and at $320^{\circ} \mathrm{C}$ the same catastophic failure is attained after 20 turns only. For the contact pressure levels selected in our simulative experiments this clearly rules out this standard coating as a potential candidate for nuclear environment and validates the ranking established by means of indentation and scratch testing.

In addition, the selected surface profiles in Fig. 4 are a help in understanding why, for specimen $\mathrm{Cr}-$ $\mathrm{E}$, the amount of room temperature wear is so high (comparable to the high temperature situation); closer examination of the corresponding profile reveals that the sharp, $\mathrm{V}$-shaped centre scar is superimposed on a $1 \mathrm{~mm}$ large, shallow track, suggesting this scar to be due to 3 body abrasion by the wear particles underneath the flat, $\varnothing 1 \mathrm{~mm}$, cemented carbide pin. 


\section{Conclusions}

We have shown that simple tensile type brittlenes as evidenced by indentation and scratch testing cannot be taken as a sufficient criterion for corresponding bittle wear mechanisms, especially when studying wear behaviour of spray coated, an-isotropic surfaces.

However a perceptible level of acoustic emission as well as cracks extending well outside the tracks in scratch testing (and radially in indentation) appear as reasonable indicators for brittle type failure in indentation and scratch testing as well as pin on disk wear testing beyond a critical level of contact pressure.

Future experiments will have to clarify the part played by wear particles and also concentrate on oxide scale generated during tribochemical reactions especially for high temperature operation.

\section{Acknoledgements :}

The authors acknoledge technical assistance by François Pierlot as well as final metallography and surface topography by A. Darbeida.

\begin{tabular}{|c|c|c|c|}
\hline Coating & $\mathrm{Cr}-\mathrm{E}$ & $\begin{array}{l}\mathrm{Cr} 3 \mathrm{C} 2-\mathrm{D} . \mathrm{G} . \\
\text { carbide binder }\end{array}$ & $\begin{array}{l}\text { Cr3C2-J.C. } \\
\text { carbide binder }\end{array}$ \\
\hline $890 \pm 40$ & $890 \pm 40$ & $890 \pm 40 \quad 440 \pm 85$ & $930 \pm 120 \quad 400 \pm 65$ \\
\hline $\begin{array}{c}\text { Scratch hardness (MPa) under } \\
10 \mathrm{~N}\end{array}$ & $550 \pm 40$ & $610 \pm 50$ & $860 \pm 50$ \\
\hline Surface rougness $\mathrm{Ra}(\mu \mathrm{m})$ & 1.6 & 1.1 & 5 \\
\hline Surface rougness $R \max (\mu \mathrm{m})$ & 20 & 11 & 35 \\
\hline
\end{tabular}

Table I : Surface hardness and roughness of tested specimens.

\begin{tabular}{|c|c|c|c|}
\hline Coating & $\begin{array}{c}\text { Indentation } \\
\mathrm{Pc}(\mathrm{N})\end{array}$ & $\begin{array}{c}\text { Scratch testing } \\
\text { Progr. loading } \mathrm{L}_{\mathrm{cl}}(\mathrm{N})\end{array}$ & $\begin{array}{c}\text { Scratch testing } \\
\text { Constant load } \\
20 \mathrm{~N}\left(\mathrm{~mm}^{-1}\right)\end{array}$ \\
\hline Cr-E & $<10$ & 10 & 60 \\
\hline Cr3C2 D.G. & $10-20$ & 20 & 20 \\
\hline Cr3C2 J.K. & $>20$ & 30 & 5 \\
\hline
\end{tabular}

Table II : Quantitative damage criteria of brittle surface cracking in high load Vickers indentation and scratch testing.

\begin{tabular}{|c|c|c|c|c|}
\hline Sliding temperature & coating & sliding mode & $\begin{array}{c}\text { wear volume from } \\
\text { weigting }\left(\mathrm{mm}^{3}\right)\end{array}$ & $\begin{array}{l}\text { wear volume from } \\
\text { SSP }\left(\mathrm{mm}^{3}\right)\end{array}$ \\
\hline 20 & $\mathrm{Cr}-\mathrm{E}$ & sliding & 1.3 & 1.3 \\
\hline 20 & Cr-E & impact + sliding & $\begin{array}{c}2.28 \text { (after } 35000 \\
\text { cycles) }\end{array}$ & \\
\hline 20 & $\mathrm{Cr} 3 \mathrm{C} 2 \mathrm{DG}$ & sliding & 0.22 & 0.23 \\
\hline 20 & $\mathrm{Cr} 3 \mathrm{C} 2 \mathrm{DG}$ & impact + sliding & 0.32 & \\
\hline 20 & $\mathrm{Cr} 3 \mathrm{C} 2 \mathrm{JK}$ & sliding & 0.23 & 0.2 \\
\hline 20 & $\mathrm{Cr} 3 \mathrm{C} 2 \mathrm{JK}$ & impact + sliding & 0.34 & \\
\hline 320 & Cr-E & sliding & 1.9 & 1.69 \\
\hline 320 & Cr-E & impact + sliding & 20 & \\
\hline 320 & $\mathrm{Cr} 3 \mathrm{C} 2 \mathrm{DG}$ & sliding & 0.98 & 1.6 \\
\hline 320 & $\mathrm{Cr} 3 \mathrm{C} 2 \mathrm{DG}$ & impact + sliding & 0.7 & \\
\hline 320 & $\mathrm{Cr} 3 \mathrm{C} 2 \mathrm{JK}$ & sliding & 1.68 & 1.7 \\
\hline 320 & $\mathrm{Cr} 3 \mathrm{C} 2 \mathrm{JK}$ & impact + sliding & 1.29 & \\
\hline
\end{tabular}

Table III : Quantitative wear data in pin on disk operation. Cemented carbide $\varnothing 1 \mathrm{~mm}$ pin after $10^{5}$ cycles. 